\title{
Inhibitory activity of postbiotic produced by strains of Lactobacillus plantarum using reconstituted media supplemented with inulin
}

\author{
Karwan Yassen Kareem ${ }^{1,2 \dagger}$, Foo Hooi Ling ${ }^{3,4^{*}}$, Loh Teck Chwen ${ }^{1,5 \dagger}$, Ooi May Foong ${ }^{3}$ and Samsudin Anjas Asmara ${ }^{1,5}$
}

\begin{abstract}
Background: The present study aimed to determine the inhibitory activity of postbiotic produced by L. plantarum using reconstituted media supplemented with different levels of inulin and to select the best combination based on the modified inhibitory activity $(\mathrm{MAU} / \mathrm{mL})$ against pathogens.

Methods: Postbiotics were produced by 6 strains of L. plantarum (RG11, RG14, RI1 1, UL4, TL1 and RS5) using reconstituted media supplemented with different levels of Inulin $(0,0.2,0.4,0.6,0.8$, and 1.0$)$ yielding 36 combinations.

Results: The combination of postbiotic and inulin had higher inhibitory activity than postbiotic alone against all indicator organisms except Pediococcus acidilactici, and E. coli. The RI1 $1+0.8 \%$ Inulin, RG $14+0.8 \%$ Inulin and $\mathrm{RG} 14+0 \%$ Inulin had significantly $(\mathrm{p}<0.05)$ higher MAU/mL against $P$. acidilactici than other treatments. The $\mathrm{Rl} 11+0.8 \%$ Inulin and RG14 + 0.4\% Inulin had a significantly $(p<0.05)$ higher MAU/mL against VRE. The MAU/mL against $L$. monocytogenes was greater in RI11 + 1.0\% Inulin, Rl11 + 0.6\% Inulin and Rl11 + 0.8\% Inulin. The combinations of RS5 + 1.0\% Inulin, RS5 + 0.8\% Inulin and RS5 + 0.6\% Inulin had greater MAU/mL against S. enterica; whereas in E. coli, the inhibitory activity had higher activity that can only be found in RS $5+0.8 \%$ Inulin.

Conclusion: Combination of postbiotics and inulin which had higher optical density tends to have lower pH which corresponds to increased inhibitory activity against indicator organisms. The results of this study show that postbiotics and inulin supplementation enable to inhibit proliferation of pathogenic bacteria.
\end{abstract}

Keywords: Lactobacillus plantarum, Postbiotic, Inulin, Modified inhibitory activity

\section{Background}

The act of feeding antibiotics to livestock has been practiced for over fifty years [1]. The mode of action of antibiotics is that they alter microbial metabolism thereby suppressing the growth of pathogenic microbes in the gut [2]. However, the use of antibiotics has been criticised for having negative impacts on animal production and health as it could have residual effects on tissues long after withdrawal. Furthermore, microbial resistance [3], genotoxicity and allergies [4] are other problems caused by the use of antibiotics in the animals.

\footnotetext{
* Correspondence: hlfoo@upm.edu.my

${ }^{\dagger}$ Equal contributors

${ }^{3}$ Department of Bioprocess Technology, Faculty of Biotechnology and Biomolecular Science, Universiti Putra Malaysia, 43400 UPM Serdang, Selangor, Malaysia

${ }^{4}$ Institute of Bioscience, Universiti Putra Malaysia, 43400 Serdang, Selangor, Malaysia

Full list of author information is available at the end of the article
}

Moreover, bacteria cause such problems as food poisoning and diarrhea. The bacteria considered as the main cause for food poisoning are L. monocytogenes, Campylobacter, Salmonella, and pathogenic E. coli. One of the most popular disease caused by food-borne bacteria worldwide is Salmonella, which is an important pathogen found in food produced by animals. This type of pathogen usually becomes widespread by trade in non-heated food products made from animal meat. The microbial strains which show resistance to antimicrobials, usually, as a result of antimicrobial procedure in animals, cause hazardous problems for public health [5].

Because of these consequences, there is increasing public awareness and pressure to search for alternatives to antibiotics [6,7]. Prebiotics, probiotics, postbiotics, and medicinal plants are common natural feed additives recently used in poultry industries to promote the immune response and 
the performance of birds. Postbiotics are substances produced in the final or intermediate stage of metabolic process in Lactic acid bacteria, while prebiotics are defined as indigestible carbohydrates that leave a desired effect on the host by selective growth stimulation or activation of one or more beneficial bacteria in a large part of the gastrointestinal tract [8]. Recently, various findings have reported that postbiotic possesses myriad beneficial probiotic effects on the growth of animals and particularly the gut health when used as additive in animal diet [9-11]. One of the features of postbiotics is their ability to reduce $\mathrm{pH}$ value thereby inhibiting opportunistic pathogens in the feed and gut of animals. In addition, postbiotics display wide inhibitory activity against various species of pathogens such as Listeria monocytogenes, Clostridium perfringens, Salmonella enterica, and Escherichia coli [12-15].

Various studies have been conducted to test the individual efficacy of postbiotics and prebiotics separately. However, no study has been conducted using the combination of prebiotics and postbiotics. Since most postbiotics exhibit probiotic effect, there could be a synergy between a prebiotic and a postbiotic. Thus, the present study was conducted to determine the inhibitory activity of postbiotic produced by 6 strains of L. plantarum using reconstituted media supplemented with different levels of inulin (a prebiotic) and to select the best combination based on the modified inhibitory activity against pathogens and an indicator bacterium.

\section{Methods}

\section{Reviving culture}

\section{Postbiotic producer}

RG11, RG14, RI11, UL4, TL1, and RS5 as Lactobacillus plantarum used in this study were previously isolated from Malaysian fermented food [16,17] and kept at $-20^{\circ} \mathrm{C}$ in MRS broth containing $20 \%(\mathrm{v} / \mathrm{v})$ glycerol. The stock cultures were revived twice in de-Mann Rogosa Sharpe (MRS) broth and incubated at $30^{\circ} \mathrm{C}$ for 48 and 24 hrs subsequently at static condition. Plate spreading was then conducted for the revived cultures, followed by 48 hrs of incubation. A single colony was picked and inoculated into $10 \mathrm{~mL}$ MRS broth and incubated for $24 \mathrm{hrs}$, followed by re-sub-culturing into $10 \mathrm{~mL}$ MRS broth and again incubating for $24 \mathrm{hrs}$. The culture was then ready to be used as an inoculum for the fermentation.

\section{Indicator microorganism}

In this study, Pediococcus acidilactici 4-46 was chosen as the indicator due to the fact that it is a common food spoilage bacterium in food products for both humans and animals [18]. The preparation of culture was same as listed in the preparation of the postbiotic producer.

\section{Pathogenic bacteria}

The reviving steps of Listeria monocytogenes L-MS, Salmonella enterica S-1000, Escherichia coli E-30 and Vancomysin Resistant Enterococci (VRE) are same as the postbiotic producer, except that nutrient media was used for the cultivation of VRE and S. enterica, incubated at $37^{\circ} \mathrm{C}$ and $30^{\circ} \mathrm{C}$, respectively. E. coli was cultivated in LB broth at $37^{\circ} \mathrm{C}$ while $L$. monocyotgenes was cultivated at $30^{\circ} \mathrm{C}$ in Listeria Enrichment media. All the cultivation was performed under the agitation speed of $150 \mathrm{rpm}$.

\section{Media preparation}

In this study, the reconstituted media of L. plantarum RG11, RG14, RI11, UL4, TL1 and RS5 were prepared for the production of postibiotic according to their composition. They were also mixed with different levels of inulin $(0.2 \%, 0.4 \%, 0.6 \%, 0.8 \%$ and $1.0 \%),(w / v)$ before autoclaved at $118^{\circ} \mathrm{C}$ for $15 \mathrm{~min}$.

\section{Production of postbiotic by L. plantarum strains}

$1 \%(\mathrm{v} / \mathrm{v})$ of inoculum was inoculated into the respective reconstituted media supplemented with different levels of inulin, and incubated at static condition at $30^{\circ} \mathrm{C}$. The postbiotic was collected after separating the bacterial cell by centrifugation at 10,000 $\times \mathrm{g}$ for $15 \mathrm{~min}$ and used for analysis.

\section{Analysis \\ Agar well diffusion assay}

The inhibitory activity of the produced postbiotics were tested against indicator microorganism, $P$. acidilactici and pathogenic microorganisms; L. monocytogenes, S. enterica, VRE and E. coli using the Agar Well diffusion method [19]. A two-fold-serial dilution of postbiotic from $2^{0}$ to $2^{5}$ was conducted using $0.85 \%(\mathrm{w} / \mathrm{v}) \mathrm{NaCl}$ solution. Each diluted postbiotic was inoculated at $20 \mu \mathrm{L}$ into the corresponding well on pre-punched MRS agar plate for $P$. acidilactici and $100 \mu \mathrm{L}$ into the pre-punched nutrient agar plate for $L$. monocytogenes, $S$. enterica and LB agar for $E$. coli while $60 \mu \mathrm{L}$ inoculated into corresponding well on nutrient agar plate for VRE. The diameter of each well was $5.5 \mathrm{~mm}$. The postbiotics were allowed to diffuse completely for $1 \mathrm{hr}$ at room temperature before overlaid with $3 \mathrm{~mL}$ of corresponding soft agar inoculated with $1 \%(\mathrm{v} / \mathrm{v})$ of $P$. acidilactici, L. monocytogenes, S. enterica, VRE, and $E$. coli, respectively. After incubation at $30^{\circ} \mathrm{C}$ for $24 \mathrm{hrs}$, the highest dilution factor with the clear zone's diameter size larger than $0.1 \mathrm{~cm}$ of the initial diameter size was recorded. The diameter of the clear zone $(\mathrm{mm})$ was measured and the modified bacteriocin activity was calculated based on the formula as shown below:

Modified bacteriocin activity: $\frac{\text { The highest dilution factor }}{\text { Volume of postbiotic }(\mathrm{mL}) * \text { diameter of zone }(\mathrm{mm})}$ 
Optical density and $\mathrm{pH}$ determination

Optical density measured the turbidity of a suspension which reflects cell mass or number of a bacterial culture.
$1 \mathrm{~mL}$ of culture from each treatment group was centrifuged at $10,000 \times \mathrm{g}$ for $15 \mathrm{~min}$. The cell pellet was washed once with $0.85 \%(\mathrm{w} / \mathrm{v})$ and the optical density was determined at

Table 1 Modified bacteriocin activity (MAU/ml) score rank of 36 combinations of postbiotics produced by using reconstituted media supplemented with different levels of inulin against pathogens

\begin{tabular}{|c|c|c|c|c|c|c|c|c|c|c|c|}
\hline \multirow[t]{2}{*}{ Treatments } & \multicolumn{2}{|l|}{ P. acidilactici } & \multicolumn{2}{|l|}{ VRE } & \multicolumn{2}{|c|}{ L. monocytogenes } & \multicolumn{2}{|l|}{ S. enterica } & \multicolumn{2}{|l|}{ E. coli } & \multirow[t]{2}{*}{ Score } \\
\hline & $\mathrm{MAU} / \mathrm{mL}$ & Rank $^{3}$ & $\mathrm{MAU} / \mathrm{mL}$ & Rank & $\mathrm{MAU} / \mathrm{mL}$ & Rank & $\mathrm{MAU} / \mathrm{mL}$ & Rank & $\mathrm{MAU} / \mathrm{mL}$ & Rank & \\
\hline$P 3^{1} .15^{2}$ & $7866.67 \pm 133.33^{\mathrm{a}}$ & 1 & $6488.84 \pm 88.88^{a}$ & 1 & $2240.00 \pm 0.00^{b c}$ & 3 & $433.33 \pm 3.33^{9}$ & 7 & - & 6 & 162 \\
\hline P3.16 & $7200.00 \pm 0.00^{b c}$ & 4 & $6044.40 \pm 88.88^{\mathrm{cd}}$ & 5 & $2453.33 \pm 53.33^{\mathrm{a}}$ & 1 & $433.33 \pm 3.33^{9}$ & 7 & _ & 6 & 157 \\
\hline P2.15 & $7866.67 \pm 133.33^{a}$ & 1 & $6399.96 \pm 0.00^{\mathrm{ab}}$ & 2 & $1226.66 \pm 26.66^{d}$ & 5 & $193.33 \pm 1.66^{k}$ & 12 & _ & 6 & 154 \\
\hline P2.11 & $7866.67 \pm 133.33^{\mathrm{a}}$ & 1 & $6399.96 \pm 0.00^{\mathrm{ab}}$ & 2 & $1226.66 \pm 26.66^{d}$ & 5 & $186.66 \pm 1.66^{k}$ & 13 & - & 6 & 153 \\
\hline P3.11 & $7066.67 \pm 133.33^{c}$ & 5 & $6222.18 \pm 88.88^{\mathrm{bc}}$ & 4 & $2186.66 \pm 53.33^{c}$ & 4 & $380.00 \pm 0.00^{\mathrm{hi}}$ & 9 & - & 6 & 152 \\
\hline P3.14 & $7200.00 \pm 0.00^{b c}$ & 4 & $5688.85 \pm 88.88^{f}$ & 9 & $2293.33 \pm 53.33^{b}$ & 2 & $386.66 \pm 3.33^{f}$ & 8 & _ & 6 & 151 \\
\hline P3.12 & $6800.00 \pm 0.00^{\text {cde }}$ & 7 & $6222.18 \pm 88.88^{\mathrm{bc}}$ & 4 & $2186.66 \pm 53.33^{c}$ & 4 & $380.00 \pm 0.00^{\mathrm{hi}}$ & 9 & _ & 6 & 150 \\
\hline P2.16 & $7466.67 \pm 133.33^{b}$ & 2 & $6399.96 \pm 0.00^{\mathrm{ab}}$ & 2 & $1120.00 \pm 0.00^{\mathrm{de}}$ & 9 & $193.33 \pm 1.66^{k}$ & 12 & - & 6 & 149 \\
\hline P2.13 & $7333.33 \pm 133.33^{b}$ & 3 & $6488.84 \pm 88.88^{a}$ & 1 & $1146.66 \pm 26.6^{\text {de }}$ & 8 & $170.00 \pm 0.00^{\prime}$ & 14 & - & 6 & 148 \\
\hline P4.15 & $7066.67 \pm 133.33^{c}$ & 5 & $5066.63 \pm 0.00^{d}$ & 10 & $1226.66 \pm 26.66^{9}$ & 5 & $446.66 \pm 3.33^{f}$ & 6 & _ & 6 & 148 \\
\hline P6.15 & $6266.67 \pm 133.33^{g h}$ & 11 & $4888.86 \pm 88.88^{g h}$ & 12 & $1200.00 \pm 0.00^{\mathrm{de}}$ & 6 & $813.33 \pm 6.66^{b}$ & 2 & $153.33 \pm 3.33^{\mathrm{a}}$ & 1 & 148 \\
\hline P6.16 & $6400.00 \pm 0.00^{f g}$ & 10 & $4888.86 \pm 88.88^{g h}$ & 12 & $1200.00 \pm 0.00^{\mathrm{de}}$ & 6 & $906.66 \pm 6.66^{a}$ & 1 & $146.66 \pm 3.33^{\mathrm{abc}}$ & 3 & 148 \\
\hline P2.14 & $7466.67 \pm 133.33^{b}$ & 2 & $6222.18 \pm 88.88^{b c}$ & 4 & $1173.33 \pm 26.6^{\mathrm{de}}$ & 7 & $170.00 \pm 0.00^{\prime}$ & 14 & - & 6 & 147 \\
\hline P3.13 & $6666.67 \pm 133.3^{\text {def }}$ & 8 & $6044.40 \pm 88.88^{c d}$ & 5 & $2186.66 \pm 53.33^{c}$ & 4 & $373.33 \pm 3.33^{i}$ & 10 & _ & 6 & 147 \\
\hline P2.12 & $7200.00 \pm 0.00^{b c}$ & 4 & $6399.96 \pm 0.00^{\mathrm{ab}}$ & 2 & $1120.00 \pm 0.00^{e}$ & 9 & $170.00 \pm 0.00^{\prime}$ & 14 & - & 6 & 145 \\
\hline P6.14 & $6266.67 \pm 133.33^{g h}$ & 4 & $5066.64 \pm 0.00^{h i}$ & 10 & $1200.00 \pm 0.00^{\mathrm{de}}$ & 6 & $786.66 \pm 6.66^{c}$ & 3 & $136.66 \pm 3.33^{c}$ & 5 & 145 \\
\hline P4.16 & $6666.67 \pm 133.3^{\mathrm{def}}$ & 8 & $4977.75 \pm 88.88^{g h}$ & 11 & $1200.00 \pm 0.00^{\mathrm{de}}$ & 6 & $446.66 \pm 3.33^{f}$ & 6 & - & 6 & 143 \\
\hline P6.12 & $6400.00 \pm 0.00^{f g}$ & 10 & $4799.97 \pm 0.00^{h i}$ & 13 & $1200.00 \pm 0.00^{\mathrm{de}}$ & 6 & $733.33 \pm 6.6^{d}$ & 4 & $140 \pm 0.00^{\mathrm{bc}}$ & 4 & 143 \\
\hline P6.11 & $6400.00 \pm 0.00^{f g h}$ & 10 & $4622.19 \pm 88.88^{\mathrm{de}}$ & 15 & $1200.00 \pm 0.00^{\mathrm{de}}$ & 6 & $746.66 \pm 6.66^{e}$ & 5 & $150 \pm 0.00^{\mathrm{ab}}$ & 2 & 142 \\
\hline P4.11 & $6933.33 \pm 133.33^{\mathrm{cd}}$ & 6 & $4977.75 \pm 88.88^{g h}$ & 11 & $1200.00 \pm 0.00^{\mathrm{de}}$ & 6 & $373.33 \pm 3.33^{i}$ & 10 & - & 6 & 141 \\
\hline P4.12 & $6933.33 \pm 133.33^{\mathrm{cd}}$ & 6 & $4888.85 \pm 88.88^{g h}$ & 12 & $1200.00 \pm 0.00^{\mathrm{de}}$ & 6 & $373.33 \pm 3.33^{i}$ & 10 & _ & 6 & 140 \\
\hline P6.13 & $6133.33 \pm 133.33^{g h}$ & 12 & $4711.08 \pm 88.88^{i}$ & 14 & $1200.00 \pm 0.00^{\mathrm{de}}$ & 6 & $786.66 \pm 6.66^{c}$ & 3 & $136.66 \pm 3.33^{c}$ & 5 & 140 \\
\hline P1.11 & $6666.67 \pm 133.3^{\text {def }}$ & 8 & $6399.96 \pm 0.0^{a b}$ & 2 & $693.33 \pm 13.33^{f}$ & 10 & $120.00 \pm 0.00^{m}$ & 15 & - & 6 & 139 \\
\hline P4.14 & $6666.67 \pm 133.3^{\text {def }}$ & 8 & $4799.97 \pm 0.00^{c}$ & 13 & $1200.00 \pm 0.00^{\mathrm{de}}$ & 6 & $380.00 \pm 0.00^{\mathrm{hi}}$ & 9 & - & 6 & 138 \\
\hline P1.12 & $6666.67 \pm 266.6^{\text {def }}$ & 8 & $6399.96 \pm 0.00^{\mathrm{ab}}$ & 2 & $693.33 \pm 13.33^{f}$ & 10 & $110.00 \pm 0.00^{\mathrm{mno}}$ & 17 & _- & 6 & 137 \\
\hline P1.16 & $6400.00 \pm 0.00^{f g}$ & 10 & $6399.96 \pm 0.00^{\mathrm{ab}}$ & 2 & $693.33 \pm 13.33^{f}$ & 10 & $108.00 \pm 1.66^{\mathrm{mno}}$ & 18 & _ & 6 & 134 \\
\hline P4.13 & $6533.33 \pm 133.3^{\mathrm{efg}}$ & 9 & $4977.75 \pm 88.88^{g h}$ & 11 & $1120.00 \pm 0.00^{e}$ & 9 & $360.00 \pm 0.00^{j}$ & 11 & - & 6 & 134 \\
\hline P1.15 & $6533.33 \pm 133.3^{\mathrm{efg}}$ & 9 & $6222.18 \pm 88.88^{\mathrm{bc}}$ & 4 & $693.33 \pm 13.33^{f}$ & 10 & $105.00 \pm 0.00^{\text {no }}$ & 19 & - & 6 & 132 \\
\hline P5.11 & $6666.67 \pm 133.3^{\text {def }}$ & 8 & $6222.18 \pm 88.88^{\mathrm{bc}}$ & 4 & $586.66 \pm 13.33^{g h}$ & 14 & $110.00 \pm 0.00^{\mathrm{mno}}$ & 17 & _ & 6 & 131 \\
\hline P1.13 & $6000.00 \pm 0.00^{h}$ & 13 & $6399.96 \pm 0.00^{\mathrm{ab}}$ & 2 & $666.66 \pm 13.33^{f g}$ & 11 & $108.00 \pm 1.66^{\mathrm{mno}}$ & 18 & - & 6 & 130 \\
\hline P5.13 & $6000.00 \pm 0.00^{h}$ & 13 & $6311.07 \pm 88.88^{\mathrm{abc}}$ & 3 & $600.00 \pm 0.00^{g h}$ & 13 & $120.00 \pm 0.00^{\mathrm{m}}$ & 15 & - & 6 & 130 \\
\hline P5.14 & $6000.00 \pm 0.00^{h}$ & 13 & $6311.07 \pm 88.88^{\mathrm{abc}}$ & 3 & $586.66 \pm 13.33^{g h}$ & 14 & $116.66 \pm 1.66^{\mathrm{mn}}$ & 16 & - & 6 & 128 \\
\hline P5.12 & $6666.67 \pm 133.3^{\text {def }}$ & 8 & $6222.18 \pm 88.88^{b c}$ & 4 & $586.66 \pm 13.33^{g h}$ & 14 & $100.00 \pm 0.00^{\circ}$ & 22 & _ & 6 & 126 \\
\hline P1.14 & $6266.67 \pm 133.3^{\text {fgh }}$ & 11 & $5955.51 \pm 88.88^{\mathrm{de}}$ & 6 & $640.00 \pm 0.00^{f g h}$ & 12 & $103.00 \pm 1.66^{\circ}$ & 20 & - & 6 & 125 \\
\hline P5.16 & $6000.00 \pm 0.00^{h}$ & 13 & $5866.63 \pm 0.00^{\mathrm{def}}$ & 7 & $600.00 \pm 0.00^{g h}$ & 13 & $101.66 \pm 1.66^{\circ}$ & 21 & - & 6 & 120 \\
\hline P5.15 & $6000.00 \pm 0.00^{h}$ & 13 & $5777.74 \pm 88.88^{e f}$ & 8 & $573.33 \pm 13.33^{h}$ & 15 & $103.33 \pm 1.66^{\circ}$ & 20 & _ & 6 & 118 \\
\hline
\end{tabular}

${ }^{\mathrm{a}-\mathrm{o}}$ Means (mean of modified bacteriocin activity $\pm \mathrm{SEM}$ ) in the same column with common superscripts are non-significantly different. ${ }^{1} \mathrm{P} 1-\mathrm{P} 6=\mathrm{different}$ postbiotics (RG11, RG14, RI11, UL4, TL1 and RS5), which were numbered 1, 2, 3, 4, 5, 6. ${ }^{2} 11-16=$ Inulin levels $(0,0.2,0.4,0.6,0.8$ and $1 \%) .{ }^{3}$ Rank of modified bacteriocin activity against single indicator strain, ${ }^{4}$ Score is the sum of single indicator score as a subtraction of 36 and rank number (score $=36$-rank). The treatment with higher score has stronger inhibitory activity against 5 above-mentioned indicator strains. It was arranged in descending order in the column. 


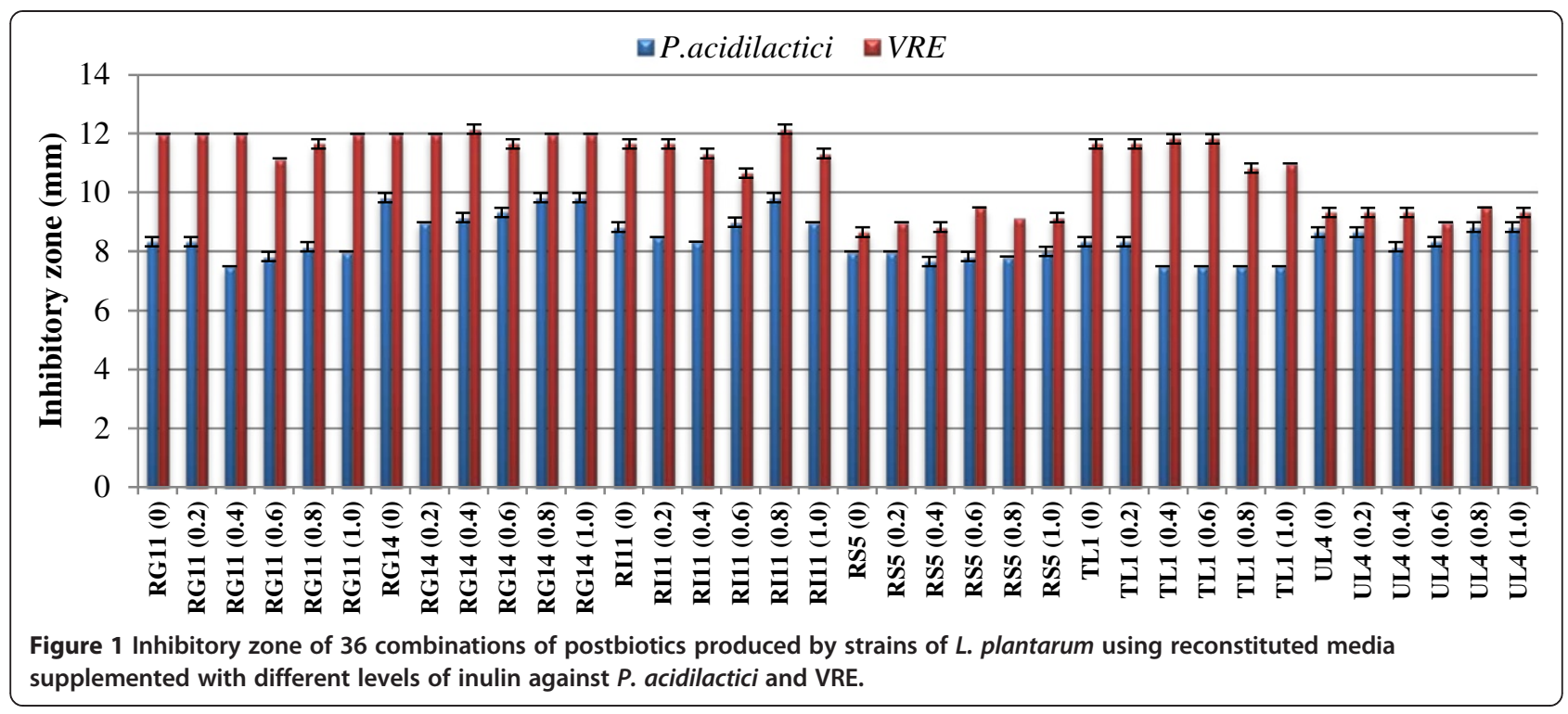

$600 \mathrm{~nm}$ using spectrophotometer (Novaspec III, Biochrom, Cambridge, UK). The $\mathrm{pH}$ of postbiotics was determined using pH meter (Mettle-Toledo., England).

\section{Statistical analysis}

The factorial ANOVA was used for data analysis in this study. Data obtained for the modified bacteriocin activity (MAU/mL), inhibitory zone, $\mathrm{pH}$, and optical density were subjected to generalized linear model of SAS. Duncan multiple range test was used to compare the significant difference of means.

\section{Results and discussion}

The modified inhibitory activity against indicator and pathogenic organisms of all the 36 combinations of postbiotics and inulin are presented in Table 1 . There were differences of inhibitory activity of different postbiotics produced by reconstituted media supplemented with inulin against different indicator organisms. The treatments P3.I5 (RI11 + 0.8\% Inulin), P2.I5 (RG14 + 0.8\% Inulin), and P2.I1 (RG14 + 0\% Inulin) had a significantly $(\mathrm{p}<0.05)$ higher $\mathrm{MAU} / \mathrm{mL}$ against $P$. acidilactici than other treatments. Treatments P3.I5 (RI11 + 0.8\% Inulin), P2.I3

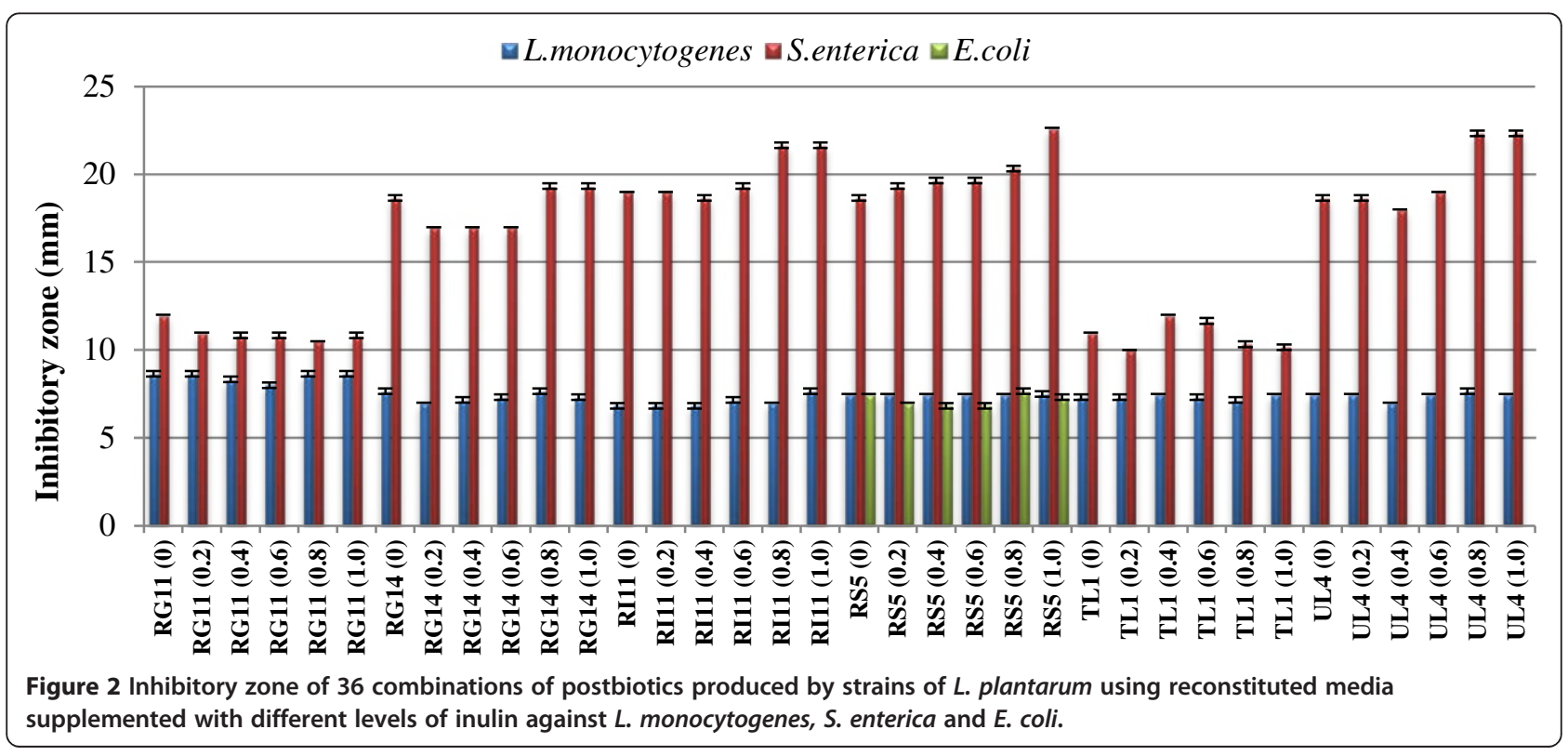


(RG14 + 0.4\% Inulin), and P2.I5 (RG14 + 0.8\% Inulin) had a significantly $(\mathrm{p}<0.05)$ higher $\mathrm{MAU} / \mathrm{mL}$ against VRE. The $\mathrm{MAU} / \mathrm{mL}$ against $L$. monocytogenes were greater in P3.I6 (RI11 + 1.0\% Inulin), P3.I4 (RI11 + 0.6\% Inulin), and P3.I5 (RI11 + 0.8\% Inulin). The P6.I6 (RS5 + 1.0\% Inulin), P6.I5 (RS5 + 0.8\% Inulin), and P6.I4 (RS5 + 0.6\% Inulin) had greater $\mathrm{MAU} / \mathrm{mL}$ against $S$. enterica. For the E. coli, inhibitory activity was detected within only RS5, where the treatment P6.I5 (RS5 + 0.8\% Inulin), P6.I1 (RS5 + $0 \%$ Inulin), and P6.I6 (RS5 + 1.0\% Inulin) had higher $\mathrm{MAU} / \mathrm{mL}$ activity.

The postbiotics produced by the 6 strains of L. plantarum used in this study exhibited broad antimicrobial activity and had the capacity to inhibit both gram positive and gram negative pathogens. This observation corroborates the findings of Sifour et al. [20], who reported that bacteriocin produced by L. plantarum F12 isolated from olive oil had broad inhibitory spectrum against $L$. monocytogenese. Similarly, Liasi et al. [13] observed that the antimicrobial agent produced by $L$. plantarum inhibited the growth of a range of gram-positive and gram-negative microorganisms such as L. monocytogenes, E. coli, Staphylococcus aureus and Salmonella enterica. The inhibitory effect, exhibited by the postbiotics and inulin combinations which were observed by the formation of clear and distinct zones around the wells, may be due to the presence of several antimicrobial compounds such as bacteriocins or organic acids [21]. Bacteriocin can be defined as proteineous compounds produced by bacteria, which exhibit bacteriostatic or bactericidal properties [14,22]. Bacteriocin from L. plantarum is a natural antimicrobial compound capable of inhibiting the growth of pathogens at molecular and cellular levels [23]. The protective effects of bacteriocin as food biopreservative and gut health have been demonstrated [24].

Organic acids act as an acidifying agent, reducing the $\mathrm{pH}$ of surrounding and survivability of non-acid-tolerant pathogens. During the production of postbiotic by $L$. plantarum strains, acetic and lactic acids are produced to promote the growth of producer cells $[14,16]$. High concentrations of organic acids and low $\mathrm{pH}$ can prevent the proliferation of food-borne pathogens and spoilage organisms $[25,26]$. In addition, the enzymatic activity of pathogens could be impaired by organic acids thus forcing the bacterial cell to utilize the remaining energy to oust excess proton $\mathrm{H}$ leading to the death of the bacteria [27]. Similarly, based on the mode of action of inulin, a prebiotic has been established. Dunkley et al. [28] and Rehman et al. [29] reported that the indirect antimicrobial effect of prebiotics could be due to production of fermentation products such as bacteriocin and short chain fatty acids capable of reducing pathogens by $\mathrm{pH}$ reduction. The production of short chain fatty acids (SCFAs) and bacteriocin capable of reducing $\mathrm{pH}$ has been reported as an indirect mechanism by which prebiotics such as inulin exert their antimicrobial influence [28]. According to Remesy et al. [30], fermentation of inulin and FOS leads to a considerable production of organic acids. It is also

Table 2 Optical density of different $L$. plantarum strains and pH of different postbiotic produced by using reconstituted media supplemented with different levels of inulin

\begin{tabular}{|c|c|c|}
\hline Treatments & OD & $\mathrm{pH}$ \\
\hline$P 1^{1} .11^{2}$ & $2.06 \pm 0.03^{e}$ & $4.05 \pm 0.008^{9}$ \\
\hline P1.12 & $2.02 \pm 0.03^{f}$ & $4.12 \pm 0.003^{e}$ \\
\hline P1.13 & $1.99 \pm 0.00^{f g}$ & $4.15 \pm 0.008^{d}$ \\
\hline P1.14 & $1.98 \pm 0.003^{9}$ & $4.15 \pm 0.003^{d}$ \\
\hline P1.15 & $1.98 \pm 0.003^{9}$ & $4.15 \pm 0.003^{d}$ \\
\hline P1.16 & $1.98 \pm 0.003^{\text {de }}$ & $4.15 \pm 0.005^{9}$ \\
\hline P2.11 & $2.00 \pm 0.00^{f}$ & $4.04 \pm 0.003^{\mathrm{e}}$ \\
\hline P2.12 & $2.00 \pm 0.003^{f g}$ & $4.06 \pm 0.003^{f g}$ \\
\hline P2.13 & $1.99 \pm 0.003^{f g}$ & $4.06 \pm 0.006^{9}$ \\
\hline P2.14 & $1.99 \pm 0.003^{9}$ & $4.07 \pm 0.003^{f}$ \\
\hline P2.15 & $2.0 \pm 0.003^{f g}$ & $4.08 \pm 0.00^{f}$ \\
\hline P2.16 & $2.0 \pm 0.003^{\mathrm{de}}$ & $4.07 \pm 0.003^{9}$ \\
\hline P3.11 & $2.16 \pm 0.006^{d}$ & $3.94 \pm 0.01^{\mathrm{h}}$ \\
\hline P3.12 & $2.16 \pm 0.003^{d}$ & $3.91 \pm 0.006^{i}$ \\
\hline P3.13 & $2.23 \pm 0.005^{b c}$ & $3.91 \pm 0.00^{i}$ \\
\hline P3.14 & $2.23 \pm 0.003^{b c}$ & $3.90 \pm 0.003^{i}$ \\
\hline P3.15 & $2.24 \pm 0.003^{\mathrm{ab}}$ & $3.87 \pm 0.003^{\mathrm{kl}}$ \\
\hline P3.16 & $2.24 \pm 0.00^{\mathrm{ab}}$ & $3.87 \pm 0.003^{k}$ \\
\hline P4.11 & $2.20 \pm 0.003^{\mathrm{cd}}$ & $3.88 \pm 0.003^{k}$ \\
\hline P4.12 & $2.18 \pm 0.006^{d}$ & $3.87 \pm 0.005^{k}$ \\
\hline P4.13 & $2.19 \pm 0.006^{\mathrm{cd}}$ & $3.84 \pm 0.003^{m}$ \\
\hline P4.14 & $2.20 \pm 0.006^{c d}$ & $3.83 \pm 0.00^{m}$ \\
\hline P4.15 & $2.24 \pm 0.003^{b}$ & $3.80 \pm 0.0035^{n}$ \\
\hline P4.16 & $2.20 \pm 0.003^{c d}$ & $3.85 \pm 0.00^{\prime}$ \\
\hline P5.11 & $1.97 \pm 0.003^{g h}$ & $4.34 \pm 0.00^{c}$ \\
\hline P5.12 & $1.94 \pm 0.005^{h}$ & $4.37 \pm 0.006^{b}$ \\
\hline P5.13 & $1.94 \pm 0.008^{\mathrm{hi}}$ & $4.37 \pm 0.003^{a b}$ \\
\hline P5.14 & $1.94 \pm 0.003^{\mathrm{hi}}$ & $4.38 \pm 0.010^{a b}$ \\
\hline P5.15 & $1.93 \pm 0.003^{h i}$ & $4.38 \pm 0.01^{\mathrm{a}}$ \\
\hline P5.16 & $1.92 \pm 0.003^{i}$ & $4.38 \pm 0.005^{\mathrm{ab}}$ \\
\hline P6.11 & $2.25 \pm 0.005^{\mathrm{ab}}$ & $3.90 \pm 0.003^{i j}$ \\
\hline P6.12 & $2.26 \pm 0.005^{\mathrm{ab}}$ & $3.88 \pm 0.005^{j k}$ \\
\hline P6.13 & $2.26 \pm 0.005^{\mathrm{ab}}$ & $3.88 \pm 0.003^{k}$ \\
\hline P6.14 & $2.27 \pm 0.005^{\mathrm{ab}}$ & $3.87 \pm 0.00^{k}$ \\
\hline P6.15 & $2.28 \pm 0.003^{\mathrm{a}}$ & $3.85 \pm 0.003^{\mathrm{kl}}$ \\
\hline P6.16 & $2.27 \pm 0.003^{\mathrm{ab}}$ & $3.85 \pm 0.003^{1 \mathrm{~m}}$ \\
\hline
\end{tabular}

${ }^{\mathrm{a}-\mathrm{n}}$ Means (mean of $\mathrm{OD}$ and $\mathrm{pH} \pm \mathrm{SEM}$ ) in the same column with common superscripts are non-significantly different. ${ }^{1} \mathrm{P} 1-\mathrm{P} 6=$ different postbiotics (RG11, RG14, RI11, UL4, TL1 and RS5), which were numbered 1, 2, 3, 4, 5, 6. ${ }^{2} 11-16=$ Inulin levels $(0,0.2,0.4,0.6,0.8$ and $1 \%)$. 
able to increase acidification of gut contents. Furthermore, prebiotics act as fermentation elements for particular members of the microbiota enhancing their numbers as well as the postbiotic of fermentation [31].

The inhibitory zone of postbiotic combinations against $P$. acidilactici and VRE is shown in Figure 1. The highest inhibitory zone against $P$. acidilactici was $9.83 \mathrm{~mm}$ in RG14 (0), RG14 (0.8), RG14 (1.0), and RI1 (0.8), whereas the highest inhibitory zone against VRE was $12.16 \mathrm{~mm}$ in RG14 (0.4) and RI11 (0.8).

The inhibitory zone of postbiotic combinations against L. monocytogenes, S. enterica, and E. coli is shown in Figure 2. The highest inhibitory zone against $L$. monocytogenes was $8.66 \mathrm{~mm}$ in RG11 (0), RG11 (0.2), RG11 (0.8), and RG11 (1.0), whereas the highest inhibitory zone against S. enterica was $22.66 \mathrm{~mm}$ in RS5 (1.0). On the other hand, in E. coli, the inhibitory activity was detected just in RS5 in which the inhibitory zone of the combination RS5 (0.8) was $7.66 \mathrm{~mm}$.

The optical density $\left(\mathrm{OD}_{600}\right)$ and $\mathrm{pH}$ of various combinations of $L$. plantarum and inulin are shown in Table 2. There are significant differences $(\mathrm{p}<0.05)$ in $\mathrm{OD}_{600}$ between different combinations of postbiotics and inulin. The mean optical density ranges from 1.92 to 2.28. The highest optical density observed in P6.I5 (RS5 $+0.8 \%$ Inulin). In contrast, the lowest OD was observed in P5.I6 (TL1 + 1.0\% Inulin). As reported by Thu et al. [32], the differences in OD could be due to variation in the physiological and biochemical properties among different strains of $L$. plantarum. Choe et al. [1] also reported different strains of $L$. plantarum tend to grow and produce various levels of metabolite which may affect the value of the OD in similar condition. However, it was observed that combinations having higher OD tend to have lower $\mathrm{pH}$. It was also observed that the combinations with low $\mathrm{pH}$ have high inhibitory activities against different indicator organisms. This observation was in line with the report of Fooks and Gibson [33] which suggests that low $\mathrm{pH}$ could be the probable mechanism of inhibitory action of the metabolites.

\section{Conclusion}

It was evident in this study that postbiotic produced by Lactobacillus plantarum RG11, RG14, RI11, UL4, TL1, and RS5 using reconstituted media supplemented with different levels of inulin have the ability to inhibit various pathogens. Also, the combinations have a stronger inhibitory activity than the postbiotic alone due to the synergistic effect of postbiotic and inulin. The increase in optical density of the combinations contributed to a lower $\mathrm{pH}$. Among the 36 treatments, P3.I5 (RI11 + 0.8\% Inulin), P3. I6 (RI11 + 1.0\% Inulin), and P2.I5 (RG14 + 0.8\% Inulin) showed a higher level of modified bacteriocin activity. The results of this study show that postbiotics and inulin supplementation enable to inhibit proliferation of pathogenic bacteria.

\section{Competing interests}

The authors declare that they have no competing interests.

\section{Authors' contributions}

FHL and LTC provided probiotic strains and method to produce postbiotic. KYK and MFO performed inhibitory tests. KYK, LTC, FHL, MFO and SAA contributed to the writing of the manuscript. All authors read and approved the final manuscript.

\section{Acknowledgements}

This project was supported by Long-Term Research Grant Scheme (LRGS) from Ministry of Education Malaysia.

\section{Author details}

${ }^{1}$ Department of Animal Science, Faculty of Agriculture, Universiti Putra Malaysia, 43400 UPM Serdang, Selangor, Malaysia. ${ }^{2}$ Department of Animal Resource, University of Salah al- Din, Erbil, Iraq. ${ }^{3}$ Department of Bioprocess Technology, Faculty of Biotechnology and Biomolecular Science, Universiti Putra Malaysia, 43400 UPM Serdang, Selangor, Malaysia. ${ }^{4}$ Institute of Bioscience, Universiti Putra Malaysia, 43400 Serdang, Selangor, Malaysia. ${ }^{5}$ Institute of Tropical Agriculture, Universiti Putra Malaysia, 43400 Serdang, Selangor, Malaysia.

Received: 14 April 2014 Accepted: 10 June 2014 Published: 14 June 2014

\section{References}

1. Choe D, Foo H, Loh T, Hair-Bejo M, Awis Q: Inhibitory property of metabolite combinations produced from lactobacillus plantarum strains. Pertanika J Trop Agric Sci 2013, 36:79-88.

2. Gadd J: Life Without Antibiotic Digestive Enhancers. In Biotechnology in the Feed Industry. Nicholasville, Kentucky, USA: Proceedings Alltechs 13th Annual Symposium; 1997:277-291.

3. Shazali N, Foo HL, Loh TC, Choe DW, Abdul Rahim R: Prevalence of antibiotic resistance in lactic acid bacteria isolated from the faeces of broiler chicken in Malaysia. Gut Pathogens 2014, 6(1). doi:10.1186/1757-4749-6-1.

4. Markovicv R: The effect of different growth promoters in broiler nutrition on performance and health status. In Master Thesis. Faculty of Veterinary Medicine. Belgrade, Serbia: University of Belgrade; 2005.

5. Forshell $L$, Wierup M: Salmonella contamination: a significant challenge to the global marketing of animal food products. Rev Sci Tech Off Int Epiz 2006, 25(2):541-554

6. McCartney A: Application of molecular biological methods for studying probiotics and the gut flora. Br J Nutr 2002, 88:29-37.

7. Williams P, Losa R: The use of essential oils and their compounds in poultry nutrition. World Poult 2001, 17:14-15.

8. Gibson GR, Roberfroid MB: Dietary modulation of the human colonic microbiota. Introducing the concept of prebiotic. J Nutr 1995, 125:1401-1412.

9. Loh TC, Thanh NT, Foo HL, HAIR-BEJO M, Azhar BK: Feeding of different levels of metabolite combinations produced by Lactobacillus plantarum on growth performance, fecal microflora, volatile fatty acids and villi height in broilers. Anim Sci J 2010, 81:205-214.

10. Choe DW, Loh TC, Foo HL, Hair-Bejo M, Awis QS: Egg production, faecal $\mathrm{pH}$ and microbial population, small intestine morphology, and plasma and yolk cholesterol in laying hens given liquid metabolites produced by Lactobacillus plantarum strains. Br Poultry Sci 2012, 53:106-115.

11. Thu TV, Loh TC, Foo HL, Yaakub H, Bejo MH: Effects of liquid metabolite combinations produced by Lactobacillus plantarum on growth performance, faeces characteristics, intestinal morphology and diarrhoea incidence in postweaning piglets. Tropl Anim Health Prod 2011, 43(1):69-75.

12. Gaggia F, Mattarelli $P$, Biavati B: Probiotics and prebiotics in animal feeding for safe food production. Int J Food Microbio/ 2010, 2010(141):S15-S28.

13. Liasi SA, Azmi T, Hassan MD, Shuhaimi M, Rosfarizan M, Ariff AB: Antimicrobial activity and antibiotic sensitivity of three isolates of lactic acid bacteria from fermented fish product, Budu. Malays J Microbio/ 2009, 5:33-37.

14. Savadogo A, Ouattara AC, Bassole HI, Traore SA: Bacteriocins and lactic acid bacteria-a minireview. Afr J Biotechnol 2006, 5:678-683. 
15. Thanh NT, Loh TC, Foo HL, HAIR-BEJO M, Azhar BK: Inhibitory activity of metabolites produced by Lactobacillus plantarum isolated from Malaysian fermented food. Int J Probiotics Prebiotics 2010, 5:37-44.

16. Foo HL, Loh TC, Law FL, Lim YS, Kuflin CN, Rusul G: Effect of feeding L. plantarum I-UL4 isolated from Malaysian Tempeh on growth performance, fecla flora and lactic acid bacteria and plasma cholesterol concentrations in post weaning rats. J Food Sci Biotechnol 2003, 12:403-408.

17. Moghadam MS, Foo HL, Leow TC, Rahim RA, Loh TC: Novel bacteriocinogenic Lactobacillus plantarum strains and their differentiation by sequence analysis of $16 \mathrm{~S}$ rDNA, 16S-23S and 23S-5S intergenic spacer regions and randomly amplified polymorphic DNA analysis. Food Technol Biotechnol 2010, 48(4):476-483.

18. Waite JG, Jones JM, Yousef AE: Isolation and identification of spoilage microorganisms using food-based media combined with rDNA sequencing: ranch dressing as a model food. Food Microbiol 2009, 26:235-239.

19. Tagg J, McGiven A: Assay system for bacteriocins. Appl Microbiol 1971, 21:943.

20. Sifour M, Tayeb I, Haddar HO, Namous H, Aissaoui S: Production and characterization of bacteriocin of Lactobacillus plantarum F12 with inhibitory activity against Listeria monocytogenes. Online J Sci Technol 2012, 2:55-61.

21. Labioui H, Elmoualdi L, El Yachioui M, Ouhssine M: Sélection de souches de bactéries lactiques antibactériennes. Bull Soc Pharm Bordeaux 2005, 144:237-250.

22. Jack RW, Tagg JR, Ray B: Bacteriocins of gram-positive bacteria. Microbiol Rev 1995, 59:171-200.

23. Drider $D$, Fimland $G$, Héchard $Y$, McMullen $L M$, Prévost $H$ : The continuing story of class Ila bacteriocins. Microbiol Mol Biol Rev 2006, 70:564-582.

24. Brashears MM, Amezquita A, Jaroni D, Steve L: Lactic acid bacteria and their uses in animal feeding to improve food safety. Adv Food Nutr Res 2005, 50:2-32

25. Adams M, Hall C: Growth inhibition of food-borne pathogens by lactic and acetic acids and their mixtures. Int J Food Sci Technol 1988, 23:287-292

26. Cintas $L$, Casaus M, Herranz C, Nes I, Hernández P: Review: bacteriocins of lactic acid bacteria. Food Sci Technol Int 2001, 7:281-305.

27. Holyoak CD, Stratford M, McMullin Z, Cole MB, Crim-mins K, Brown AJP, Coote P: Activity of the membrane H1-ATPase and optimal glycolyticflux required for rapid adaptation and growth in the presence of weak acid preservative sorbic acid. Appl Environ Microbiol 1996, 62:3158-3164.

28. Dunkleya KD, Callaway TR, Chalovaa VI, McReynolds JL, Hume ME, Dunkley CS, Kubena LF, Nisbet DJ, Ricke SC: Foodborne Salmonella ecology in the avian gastrointestinal tract. Anaerobe 2009, 15:26-35.

29. Rehman H, Vahjen W, Kohl-Parisini A, ljaz A, Zentek J: Influence of fermentable carbohydrates on the intestinal bacteria and enteropathogens in broilers. Worlds Poult Sci J 2009, 65:75-90

30. Re'me'sy C, Levrat MA, Gamet L: Cecal fermentations in rats fed oligosaccharides (inulin) are modulated by dietary calcium level. Am J Physiol 1993, 264:G855-G862.

31. Yang Y, lji P, Choct M: Dietary modulation of gut microflora in broiler chickens: a review of the role of six kinds of alternatives to in-feed antibiotics. Worlds Poult Sci J 2009, 65:97-114.

32. Thu TV, Foo HL, Loh TC, Bejo MH: Inhibitory activity and organic acid concentrations of metabolite combinations produced by various strains of Lactobacillus plantarum. Afr J Biotechnol 2011, 10(8):1359-1363.

33. Fooks $\sqcup$, Gibson GR: In vitro investigations of the effect of probiotics and prebiotics on selected human intestinal pathogens. FEMS Microbiol Ecol 2002, 39:67-75.

doi:10.1186/1757-4749-6-23

Cite this article as: Kareem et al:: Inhibitory activity of postbiotic produced by strains of Lactobacillus plantarum using reconstituted media supplemented with inulin. Gut Pathogens 2014 6:23.

\section{Submit your next manuscript to BioMed Central and take full advantage of:}

- Convenient online submission

- Thorough peer review

- No space constraints or color figure charges

- Immediate publication on acceptance

- Inclusion in PubMed, CAS, Scopus and Google Scholar

- Research which is freely available for redistribution

Submit your manuscript at www.biomedcentral.com/submit
C Biomed Central 